\title{
Ten years' clinical experience with biosimilar human growth hormone: a review of efficacy data
}

\author{
This article was published in the following Dove Press journal: \\ Drug Design, Development and Therapy \\ 16 May 2017 \\ Number of times this article has been viewed
}

\author{
Juan Pedro López-Siguero' \\ Roland Pfäffle ${ }^{2}$ \\ Philippe Chanson ${ }^{3}$ \\ Mieczyslaw Szalecki ${ }^{4,5}$ \\ Nadja Höbel ${ }^{6}$ \\ Markus Zabransky ${ }^{6}$
}

'Servicio de Endocrinología Pediátrica, Hospital Materno-Infantil, Hospital Regional Universitario de Málaga, Spain; ${ }^{2}$ University Children's Hospital Leipzig, Germany; ${ }^{3}$ Department of Endocrinology and Reproductive Diseases, Hôpital de Bicêtre,

Hôpitaux Universitaires Paris-Sud, Assistance Publique-Hôpitaux de

Paris and University Paris-Sud, Le Kremlin-Bicêtre, France; ${ }^{4} \mathrm{Clinic}$ of Endocrinology and Diabetology, Children's Memorial Health Institute, Warsaw, Poland; ${ }^{5}$ Faculty of Medicine and Health Sciences UJK, Kielce, Poland; ${ }^{6}$ Sandoz Biopharmaceuticals, Hexal AG, Holzkirchen, Germany
Correspondence: Markus Zabransky Sandoz Biopharmaceuticals, Hexal AG, Industriestr 25, D-83607 Holzkirchen, Germany

Tel +4980244762255

Fax +49802 44762262

Email markus.zabransky@sandoz.com

\begin{abstract}
In 2006, the European Medicines Agency (EMA) approved Omnitrope ${ }^{\circledR}$ as a biosimilar recombinant human growth hormone ( $\mathrm{rhGH})$, on the basis of comparable quality, safety, and efficacy to the reference medicine (Genotropin ${ }^{\circledR}$, Pfizer). Data continue to be collected on the long-term efficacy of biosimilar rhGH from several on-going postapproval studies. Particular topics of interest include efficacy in indications granted on the basis of extrapolation, and whether efficacy of growth hormone treatment is affected when patients are changed to biosimilar rhGH from other rhGH products. Data from clinical development studies and 10 years of postapproval experience affirm the clinical efficacy and effectiveness of biosimilar rhGH across all approved indications. In addition, the decade of experience with biosimilar rhGH since it was approved in Europe confirms the scientific validity of the biosimilar pathway and the approval process. Concerns about clinical effect in extrapolated indications, and also about the impact of changing from other rhGH preparations, have been alleviated. Biosimilar rhGH is an effective treatment option for children who require therapy with rhGH.
\end{abstract}

Keywords: recombinant human growth hormone, Omnitrope ${ }^{\circledR}$, biosimilar

\section{Introduction}

Growth hormone (GH, somatropin) is a potent metabolic hormone that is important for the metabolism of lipids, carbohydrates, and proteins. In children who have a deficiency of endogenous GH, use of GH replacement therapy stimulates linear growth and increases growth rate. ${ }^{1} \mathrm{GH}$ therapy is also approved for pediatric use in other indications, such as children with Turner syndrome (TS) and Prader-Willi syndrome (PWS), short children born small for gestational age (SGA), and children with chronic renal insufficiency. ${ }^{1}$ In all pediatric indications, early diagnosis and initiation of GH treatment is important for optimizing the effects of treatment. In adults and children, somatropin maintains a normal body composition by increasing nitrogen retention and stimulation of skeletal muscle growth and by mobilizing body fat. ${ }^{1,2}$

GH replacement therapy with recombinant human growth hormone (rhGH) has been available since 1985. ${ }^{3}$ In 2006, the European Medicines Agency (EMA) approved Omnitrope $^{\circledR}$ (biosimilar rhGH; Sandoz, Kundl, Austria) on the basis of comparable quality, safety, and efficacy to the reference medicine (Genotropin ${ }^{\circledR}$, Pfizer). Data continue to be collected on the long-term efficacy of biosimilar rhGH from several ongoing postapproval studies. Particular topics of interest include efficacy in indications granted on the basis of extrapolation, and whether the efficacy of GH treatment is affected when patients are changed to biosimilar rhGH from other rhGH products. This paper reviews the efficacy of biosimilar rhGH during its clinical development program and the subsequent 10 years of postmarketing clinical use. submit your manuscript Dovepress f http://dx.doi.org/10.214 (c) ${ }_{\mathrm{BY}} \mathrm{NC}$ and incorporate the Creative Commons Attribution - Non Commercial (unported, v3.0) License (http://creativecommons.org/licenses/by-nc/3.0/). By accessing the work you hereby accept the Terms. Non-commercial uses of the work are permitted without any further permission from Dove Medical Press Limited, provided the work is properly attributed. For permission for commercial use of this work, please see paragraphs 4.2 and 5 of our Terms (https://www.dovepress.com/terms.php). 


\section{Efficacy in Phase III studies}

A summary of the clinical studies in the Omnitrope development program is provided in Table 1 . The objectives of the Phase III clinical development program for biosimilar rhGH were to demonstrate its therapeutic efficacy and clinical comparability with the reference medicine. The AQ study was a multicenter, randomized, controlled, open-label Phase III study of children ( $\mathrm{n}=89$ ) with growth hormone deficiency (GHD). ${ }^{4,5}$ This study was designed to compare the efficacy and safety of biosimilar rhGH with the reference medicine and also assessed the long-term ( 7 years of treatment) efficacy and safety of biosimilar rhGH. Efficacy parameters assessed included height, height standard deviation score (HSDS), height velocity (HV), and HV standard deviation score (HVSDS). Clinical comparability between biosimilar rhGH and the reference medicine was demonstrated within 9 months of treatment. ${ }^{4}$

For example, the baseline-adjusted difference between biosimilar rhGH and the reference medicine in mean $\mathrm{HV}$ was $-0.20 \mathrm{~cm} /$ year (95\% confidence interval [CI]: -1.34 , 0.94) and in mean HVSDS was 0.76 (95\% CI: $-0.57,2.10)$ after 9 months. Long-term efficacy (up to 7 years) of biosimilar

Table I Overview of Omnitrope ${ }^{\circledR}$ studies

\begin{tabular}{|c|c|c|c|c|c|c|}
\hline Study & Study design & Sample size & Key objectives & Main inclusion criteria & Treatment & Assessments \\
\hline AQ study 4,5 & $\begin{array}{l}\text { Phase III, } \\
\text { multicenter, } \\
\text { randomized, } \\
\text { controlled, open- } \\
\text { label, } 84 \text { months }\end{array}$ & 89 & $\begin{array}{l}\text { Compare the } \\
\text { efficacy and safety } \\
\text { of Omnitrope }{ }^{\circledR} \text { with } \\
\text { Genotropin }{ }^{\circledR} \text { and } \\
\text { assess the long-term } \\
\text { efficacy and safety of } \\
\text { Omnitrope }{ }^{\circledR}\end{array}$ & $\begin{array}{l}\text { - Idiopathic GHD, aged } 2-14 \text { years } \\
\text { - Prepubertal } \\
\text { - Treatment naïve } \\
\text { - Height }<-2.0 \text { SDS } \\
\text { - Height velocity }<-1.0 \text { SDS } \\
\text { - Centrally read BA retardation } \\
\text { on radiograph }\end{array}$ & $\begin{array}{l}\text { Omnitrope }^{\circledR} \\
5 \mathrm{mg} / \mathrm{mL} \\
\text { lyophilized, } \\
\text { Omnitrope } \\
3.3 \mathrm{mg} / \mathrm{mL} \text { liquid } \\
\text { or reference } \\
\text { project }\end{array}$ & $\begin{array}{l}\text { Primary: height, } \\
\text { HSDS, HV, HVSDS } \\
\text { Secondary: serum } \\
\text { IGF-I and IGFBP-3 } \\
\text { Additional: BA }\end{array}$ \\
\hline Lyo study ${ }^{4,6}$ & $\begin{array}{l}\text { Phase III, } \\
\text { multicenter, } \\
\text { open-label, } \\
\text { noncomparative, } \\
48 \text { months }\end{array}$ & 51 & $\begin{array}{l}\text { Assess the long- } \\
\text { term efficacy } \\
\text { and safety of } \\
\text { Omnitrope }{ }^{\circledR} \\
\text { lyophilized } \\
\text { formulation }\end{array}$ & $\begin{array}{l}\text { - Idiopathic GHD, aged }>2 \text { years } \\
\text { - Prepubertal } \\
\text { - Treatment naïve } \\
\text { - Height }<-2.0 \text { SDS } \\
\text { - Height velocity }<-1.0 \text { SDS } \\
\text { - } \text { BA } \leq 9 \text { years (girls), } \leq 10 \text { years } \\
\text { (boys) } \\
\text { - BA over chronological age delay } \\
\text { of at least I year }\end{array}$ & $\begin{array}{l}\text { Omnitrope }^{\circledast} \\
5 \mathrm{mg} / \mathrm{mL} \\
\text { lyophilized }\end{array}$ & $\begin{array}{l}\text { Primary: height, } \\
\text { HSDS, HV, HVSDS } \\
\text { Secondary: serum } \\
\text { IGF-I and IGFBP-3 } \\
\text { Additional: BA }\end{array}$ \\
\hline $\begin{array}{l}\text { Spanish } \\
\text { study }\end{array}$ & $\begin{array}{l}\text { Phase III, } \\
\text { multicenter, } \\
\text { open-label, } \\
\text { noncomparative }\end{array}$ & 70 & $\begin{array}{l}\text { Assess the long- } \\
\text { term efficacy } \\
\text { and safety of } \\
\text { Omnitrope }^{\circledR} \text { liquid }\end{array}$ & $\begin{array}{l}\text { - GHD, aged 4-12 years } \\
\text { - Prepubertal } \\
\text { - Treatment naïv } \\
\text { - Height }<-2.0 \text { SDS } \\
\text { - Height velocity }<-1.0 \text { SDS } \\
\text { - Centrally read BA retardation } \\
\text { on radiograph of left hand and } \\
\text { wrist }\end{array}$ & $\begin{array}{l}\text { Omnitrope }{ }^{\circledR} \\
3.3 \mathrm{mg} / \mathrm{mL} \text { liquid }\end{array}$ & $\begin{array}{l}\text { Primary: height, } \\
\text { HSDS, HV, HVSDS } \\
\text { Secondary: serum } \\
\text { IGF-I and IGFBP-3 } \\
\text { Additional: BA }\end{array}$ \\
\hline $\begin{array}{l}\text { PATRO } \\
\text { Children } \\
\text { (ongoing) }\end{array}$ & $\begin{array}{l}\text { Postmarketing, } \\
\text { international, } \\
\text { observational, } \\
\text { longitudinal, } \\
\text { noninterventional }\end{array}$ & $5,007^{a}$ & $\begin{array}{l}\text { Assess the long- } \\
\text { term efficacy } \\
\text { and safety of } \\
\text { Omnitrope }^{\circledR}\end{array}$ & $\begin{array}{l}\text { - Infants, children, and adolescents } \\
\text { - Currently or previously receiving } \\
\text { Omnitrope }{ }^{\circledR} \text { treatment }\end{array}$ & Omnitrope $^{\circledR}$ & $\begin{array}{l}\text { Primary: HSDS, } \\
\text { HV, HVSDS } \\
\text { Additional: IGF-I, } \\
\text { IGFBP-3, body } \\
\text { composition, } \\
\text { and BMI }\end{array}$ \\
\hline $\begin{array}{l}\text { SGA } \\
\text { study }{ }^{11,12} \\
\text { (ongoing) }\end{array}$ & $\begin{array}{l}\text { Phase IV, } \\
\text { open-label, } \\
\text { noncomparative, } \\
\text { multicenter }\end{array}$ & $278^{b}$ & $\begin{array}{l}\text { Assess the efficacy } \\
\text { and safety of } \\
\text { Omnitrope }^{\circledR} \text {, and } \\
\text { the long-term effect } \\
\text { of Omnitrope }{ }^{\circledR} \text { on } \\
\text { the development } \\
\text { of diabetes in SGA } \\
\text { patients }\end{array}$ & $\begin{array}{l}\text { - Prepubertal children born SGA } \\
\text { - Height }<-2.5 \text { SDS and parental } \\
\text { adjusted SDS }<-1.0 \\
\text { - Birth weight and/or length } \\
<-2 \text { SDS } \\
\text { - Height velocity SDS }<0 \text { during } \\
\text { the last year by } 4 \text { years of } \\
\text { age or later }\end{array}$ & Omnitrope ${ }^{\circledR}$ & $\begin{array}{l}\text { Efficacy: height, } \\
\text { HSDS, HV, HVSDS } \\
\text { Additional: IGF-I, } \\
\text { IGFBP-3, fasting } \\
\text { plasma glucose, } \\
\text { insulin levels, } \\
\text { and glycated } \\
\text { hemoglobin } \\
\text { (HbAIc) }\end{array}$ \\
\hline
\end{tabular}

Notes: aSample size in July 2016; 'bample size in 2015.

Abbreviations: BA, bone age; BMI, body mass index; GHD, growth hormone deficiency; HSDS, height standard deviation score; HV, height velocity; HVSDS, height velocity standard deviation score; SDS, standard deviation score; SGA, small for gestational age. 
Table 2 Development of efficacy parameters in the Lyo study 4,6

\begin{tabular}{|c|c|c|c|c|c|c|}
\hline Treatment & Months & No of patients & $\begin{array}{l}\text { Mean }(\mathrm{SD}) \\
\text { height }(\mathrm{cm})\end{array}$ & $\begin{array}{l}\text { Mean (SD) } \\
\text { HSDS }^{\mathrm{a}}\end{array}$ & $\begin{array}{l}\text { Mean (SD) } \\
\text { HV (cm/year) }\end{array}$ & $\begin{array}{l}\text { Mean (SD) } \\
\text { HVSDS }^{b}\end{array}$ \\
\hline Omnitrope ${ }^{\circledR}$ & 0 & 51 & $111.9(15.5)$ & $-2.97(0.87)$ & $3.72(1.40)$ & $-2.52(1.68)$ \\
\hline $5 \mathrm{mg} / \mathrm{mL}$ lyophilized & 9 & 51 & I20.3 (I4.4) & $-2.25(0.74)$ & $1 \mathrm{I} .13(2.8 \mathrm{I})$ & $6.05(3.37)$ \\
\hline \multirow[t]{4}{*}{ formulation } & 12 & 51 & $122.3(\mid 4.3)$ & $-2.15(0.74)$ & $10.39(2.50)$ & $5.22(2.96)$ \\
\hline & 15 & 50 & $123.9(13.9)$ & $-2.02(0.73)$ & $9.27(2.36)$ & $4.0 \mathrm{I}(2.8 \mathrm{I})$ \\
\hline & 24 & 50 & I29.4 (I3.9) & $-1.76(0.75)$ & $7.58(1.63)$ & $2.09(2.25)$ \\
\hline & 48 & 46 & | $42.8(\mid 4.0)$ & $-I . I(I .0)$ & $6.3(1.9)$ & $\mathrm{I} .4(2.5)$ \\
\hline
\end{tabular}

Notes: aData based on local growth charts; 'Tanner peak-centered data.

Abbreviations: HSDS, height standard deviation score; HV, height velocity; HVSDS, height velocity standard deviation score; SD, standard deviation.

rhGH was also shown, with significant improvements observed in all four parameters between baseline and end of treatment. ${ }^{5}$

A second study (Lyo study) was a noncomparative study of biosimilar rhGH $5 \mathrm{mg} / \mathrm{mL}$ lyophilized formulation in children $(n=51)$ with GHD. ${ }^{4,6}$ The primary efficacy parameters assessed were height, HSDS, HV, and HVSDS. Efficacy was demonstrated by statistically significant increases in the efficacy parameters from baseline. For each, the mean differences were statistically significant between baseline and all subsequent visits (up to 48 months; Table 2).

A third study assessed the efficacy and safety of longterm (up to 5 years) treatment with biosimilar rhGH $3.3 \mathrm{mg} /$ $\mathrm{mL}$ liquid formulation in children with GHD $(\mathrm{n}=70) .^{7}$ After 4 years, significant increases (compared with baseline) were recorded in mean height (31.1 cm [95\% CI: 29.6, 32.6]), HSDS (1.42 [95\% CI: 1.13, 1.70]), HV $(2.4 \mathrm{~cm}$ [95\% CI: 1.7, 3.1]), and HVSDS (3.5 [95\% CI: 2.7, 4.3]) values. After 5 years, those patients still growing were offered to remain on treatment (as in usual clinical practice) and continued to be monitored to determine adult height $(\mathrm{n}=39) .{ }^{8}$ The results for all auxological parameters evaluated (height, HSDS, and HV) indicate that rhGH therapy elicited a positive growth response and led to normalization of height parameters. In the initial Phase III trial, the projected final height values were an average height gain of 12-18 cm, leading to final adult height of $157.7 \mathrm{~cm}$ for females and $167.5 \mathrm{~cm}$ for males. ${ }^{7}$ At the end of the extension period, the average height gain was $11.6 \mathrm{~cm}$ for females and $18.9 \mathrm{~cm}$ for males, and the mean adult height achieved was $157.6 \mathrm{~cm}$ in females and $165.5 \mathrm{~cm}$ in males.

\section{Efficacy in postapproval studies and extrapolated indications}

Several postapproval studies of biosimilar rhGH are ongoing and continue to provide data for biosimilar rhGH in pediatric GHD and also in indications granted on the basis of extrapolation. The PAtients TReated with Omnitrope ${ }^{\circledR}$ (PATRO) Children study began in 2006 and is an ongoing, long-term, postmarketing surveillance (PMS) program; the long-term efficacy of biosimilar rhGH is a secondary objective. ${ }^{9}$ As of July 2016, 5,007 patients were enrolled in the PATRO Children study; mean (standard deviation [SD]) duration of treatment with biosimilar rhGH was 32.4 (22.8) months. ${ }^{10}$ The majority of patients included have GHD $(n=2,854,57 \%)$; there are also a relatively large number of patients included with a diagnosis of SGA $(n=1,280,26 \%)$, TS $(n=228,5 \%)$, and PWS ( $\mathrm{n}=154,3 \%)$. Up to 4 years of treatment with biosimilar rhGH resulted in significant improvements in growth parameters across all indications; height gains were, as expected, greater in naïve patients than in pretreated patients (see Figure 1 for examples - GHD and SGA). ${ }^{10}$ Results in different indications are also positive. For example, among TS patients who were GH treatment-naïve on study entry, HSDS improved from -3.05 at baseline to -1.77 at 4 years. Among treatment-naïve PWS patients, HSDS improved from -1.60 to -0.39 .

Another ongoing study with biosimilar rhGH is the largest prospective clinical study of rhGH yet conducted in SGA patients. ${ }^{11}$ This Phase IV study began in 2007 and has enrolled 278 children, with 249 children completing 2 years of treatment. ${ }^{12}$ Treatment with biosimilar rhGH was effective; mean HSDS was -3.39 at baseline, -2.57 at 1 year, and -2.15 at 2 years of treatment. Mean HVSDS (peak-centered) also improved from -2.13 at baseline to +4.16 at 1 year and +2.23 at 2 years.

\section{Analyses of pooled data from Phase III, Phase IV, and PMS in children}

Data from three Phase III studies (interventional), the Phase IV study in SGA children (interventional), and the PATRO Children PMS (observational) were pooled for various analyses of efficacy. This pooled efficacy population consisted of all patients diagnosed with GHD and SGA who had an evaluable height assessment after 6 months of treatment; for PATRO Children, only subjects who 
A

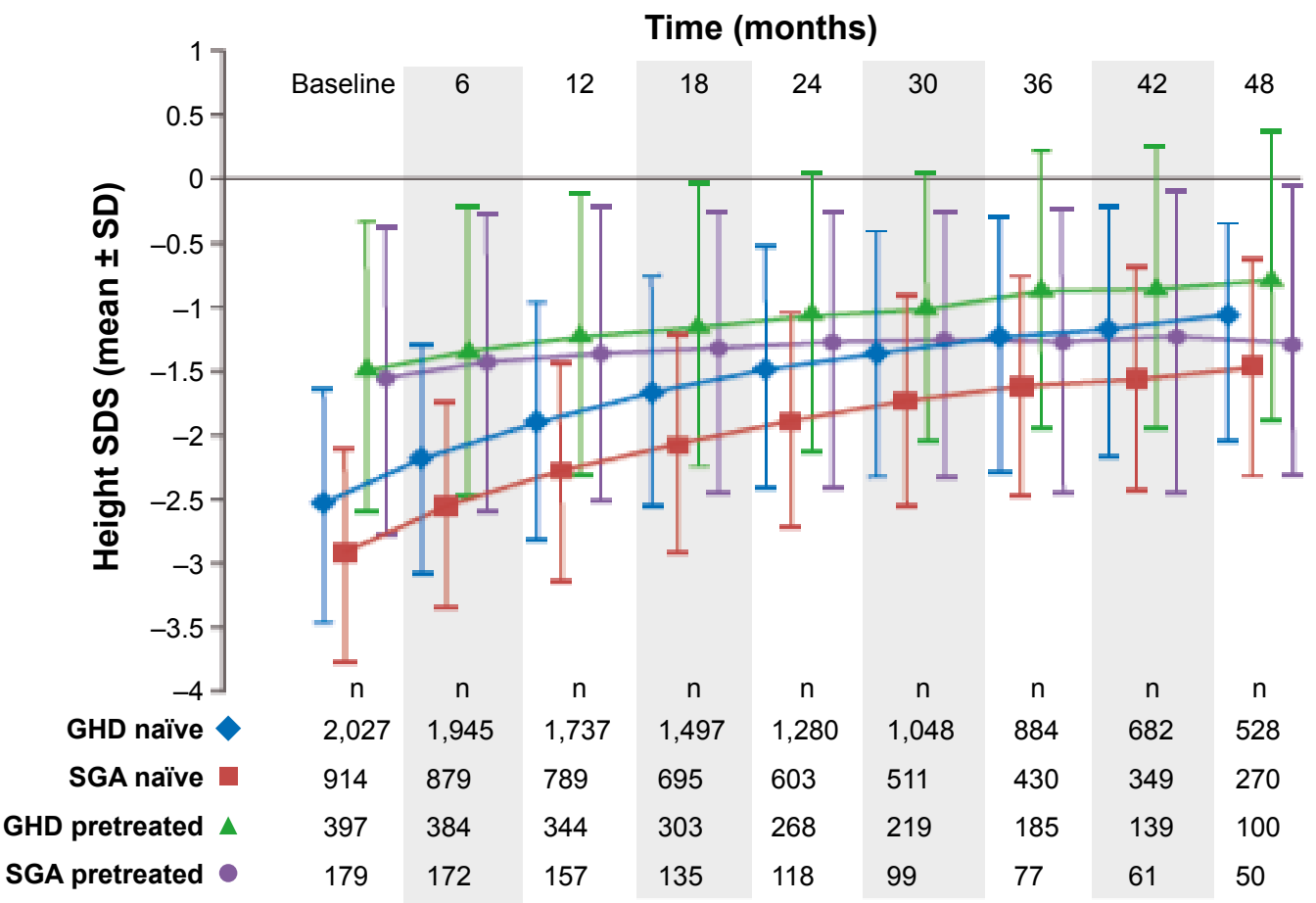

B

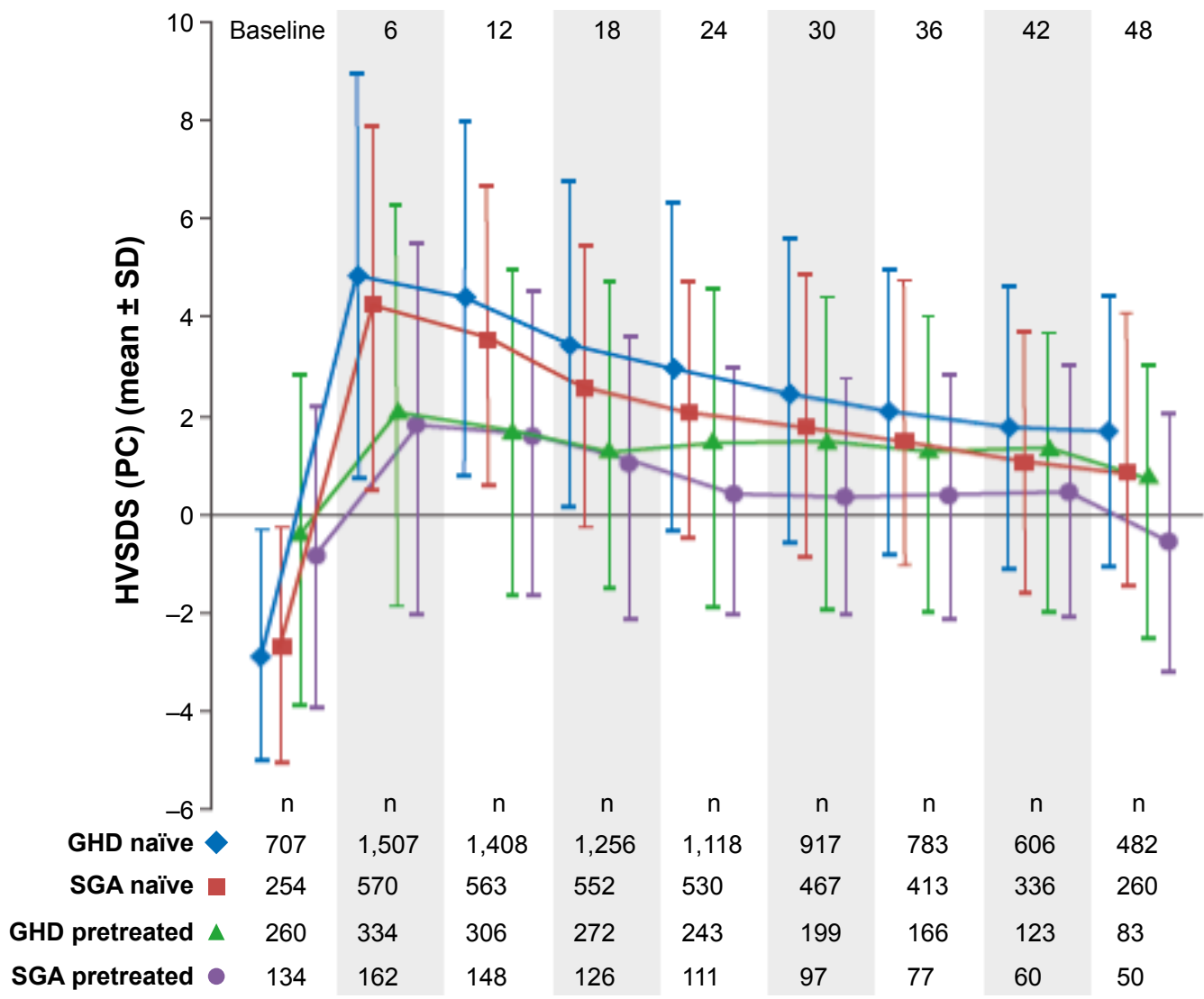

Figure I Height SDS (A) and HVSDS (B) for pretreated and growth hormone-naive GHD and SGA patients following 4 years of Omnitrope ${ }^{\circledR}$ treatment.

Abbreviations: GHD, growth hormone deficiency; HVSDS, height velocity standard deviation score; PC, peak-centered; SD, standard deviation; SDS, standard deviation score; SGA, small for gestational age. 


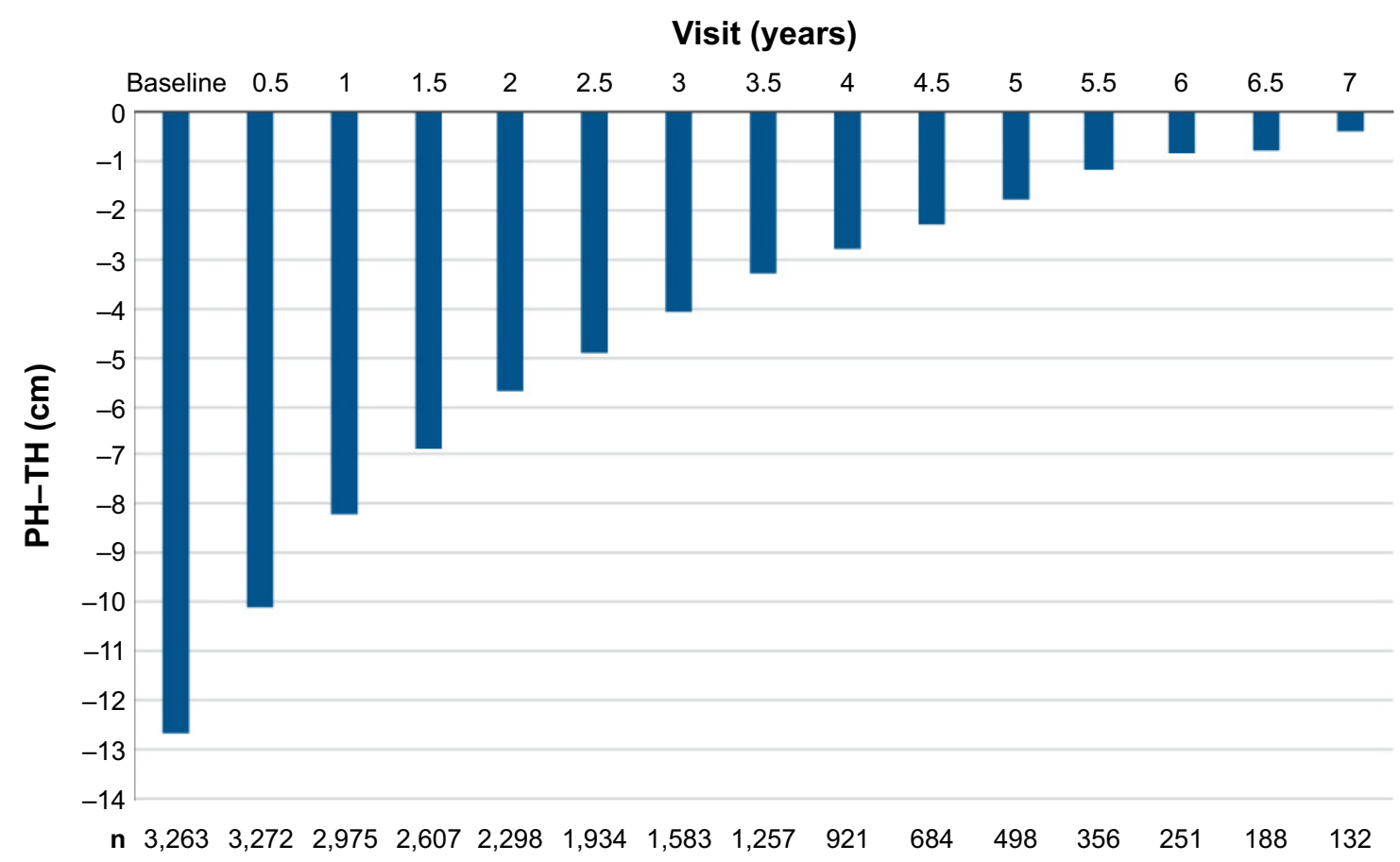

Figure 2 Difference in projected height compared with target height ( $\mathrm{PH}-\mathrm{TH})$ by visit (whole pooled efficacy population).

were GH treatment-naïve on study entry were included. Growth parameters were used as calculated in each original study (local growth references used where possible). Projected height and target height were also calculated. Growth parameters were also separately analyzed for subjects in the Phase III studies (pooled), the SGA Phase IV study, and PATRO Children. The pooled efficacy population comprised 3,582 subjects (3,103 from PATRO Children, 273 from the SGA Phase IV study, and 206 from Phase III

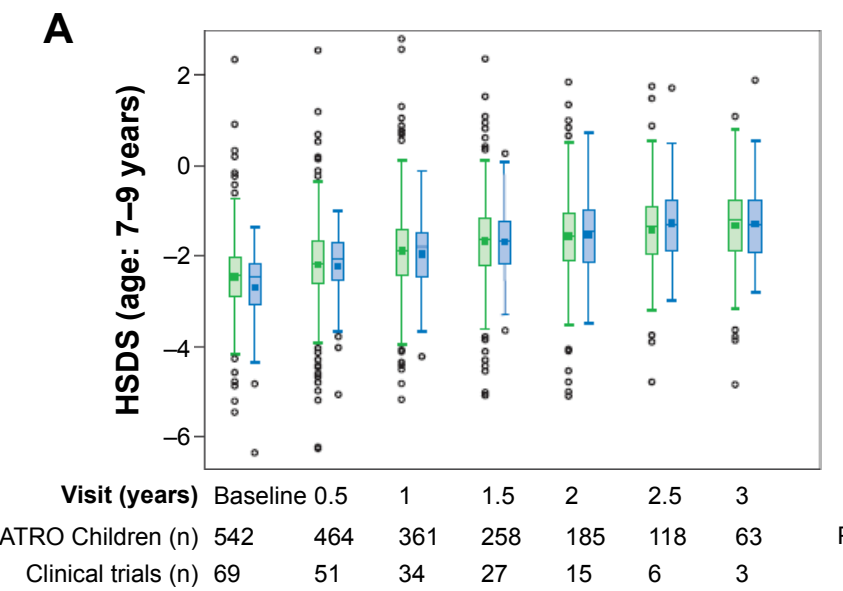

studies). Figure 2 shows projected height minus target height for the whole pooled efficacy population, demonstrating clearly the benefit of treatment with rhGH. At the start of the treatment, the difference between projected height and target height was $-12.6 \mathrm{~cm}$; after 7 years' treatment, the difference was only $-0.4 \mathrm{~cm}$.

A comparison of growth parameters between subjects in the interventional and observational (PMS) studies is shown in Figures 3 (GHD) and 4 (SGA). The examples shown are

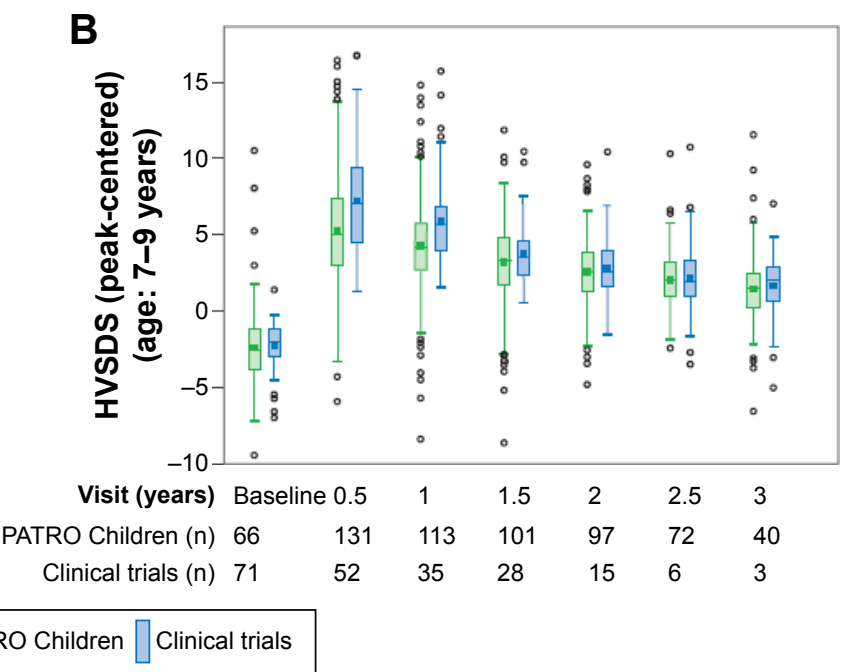

Figure 3 HSDS (A) and HVSDS (B) by visit for GHD subjects: comparison of clinical (interventional) and observational (PATRO Children) studies of Omnitrope ${ }^{\circledR}$ (unpublished data, June 2016).

Abbreviations: GHD, growth hormone deficiency; HSDS, height standard deviation score; HVSDS, height velocity standard deviation score. 

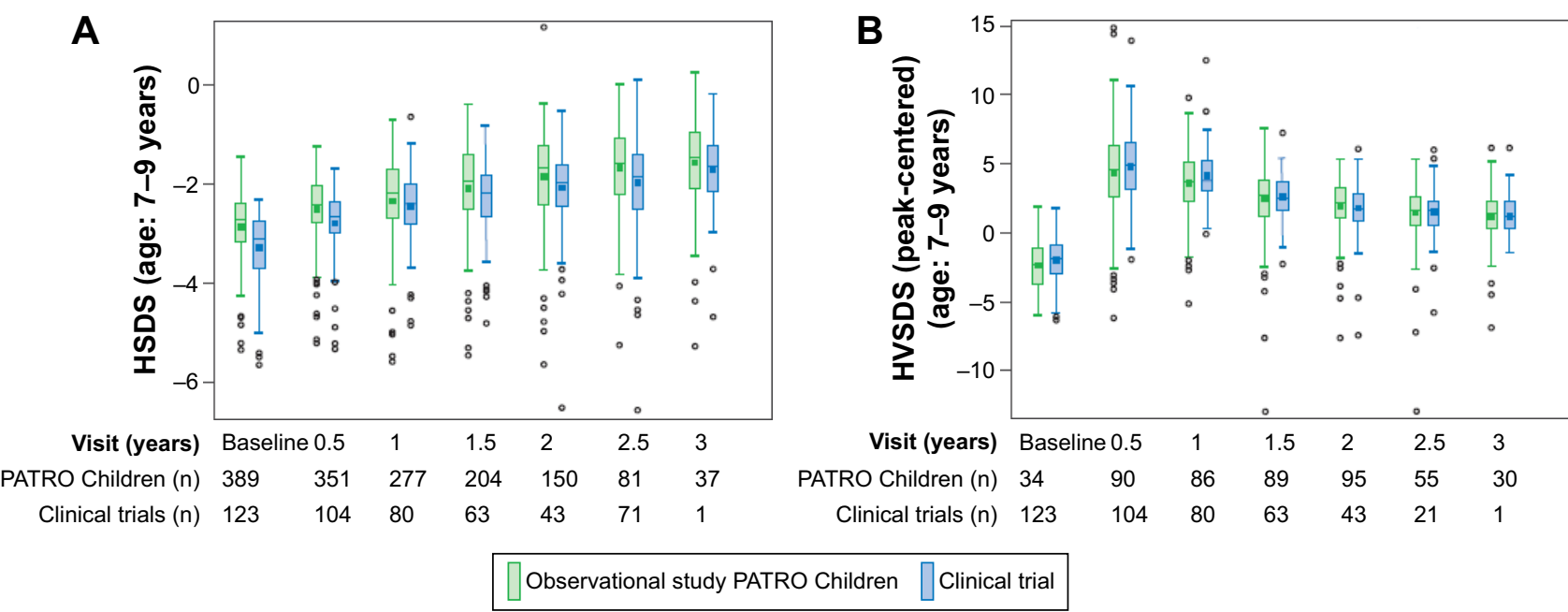

Figure 4 HSDS (A) and HVSDS (B) by visit for SGA subjects: comparison of clinical (interventional) and observational (PATRO Children) studies of Omnitrope ${ }^{\circledR}$. Abbreviations: HSDS, height standard deviation score; HVSDS, height velocity standard deviation score; SGA, small for gestational age.

for patients aged 7-9 years (prepubertal) at baseline. The efficacy of biosimilar rhGH reported from interventional studies is confirmed by the data from the PATRO Children observational study.

\section{Changing to Omnitrope ${ }^{\circledR}$ from other rhGH treatments}

An analysis of Phase III clinical data assessed the impact on efficacy and safety of changing from the reference rhGH medicine to biosimilar rhGH. ${ }^{13}$ Changing from the reference medicine to biosimilar rhGH had no negative impact on efficacy; growth outcomes and effects on IGF-I and IGFBP-3 continued as expected and showed no appreciable difference to children treated continuously with biosimilar rhGH. ${ }^{13}$

A retrospective study, conducted using an integrated database, examined the effectiveness of biosimilar rhGH in children ( $\mathrm{n}=103$ ) with GHD, idiopathic short stature (ISS), and TS who changed from a non-biosimilar rhGH rhGH preparation during routine clinical care. ${ }^{14}$ The growth trajectories of rhGH-treated patients were not negatively impacted by changing to biosimilar rhGH, and growth rates remained as expected prior to the switch. ${ }^{14}$

\section{Summary}

Data from clinical development studies and 10 years of postapproval experience confirm the clinical efficacy and effectiveness of biosimilar rhGH across all approved indications. The decade of experience with biosimilar rhGH since it was approved in Europe affirms the scientific validity of the biosimilar pathway and the approval process. Concerns about clinical effect in extrapolated indications, and also about the impact of changing from other rhGH preparations, have been alleviated. Biosimilar rhGH is an effective treatment option for children who require therapy with rhGH.

\section{Acknowledgments}

Medical writing assistance was provided by Tony Reardon of Spirit Medical Communications Ltd, funded by Sandoz $\mathrm{GmbH}$.

\section{Disclosure}

$\mathrm{NH}$ and $\mathrm{MZ}$ are employees of Sandoz International $\mathrm{GmbH} /$ Hexal AG. PC has received unrestricted research and educational grants from Ipsen, Novartis, Novo-Nordisk, and Pfizer as Head of the Department of Endocrinology and Reproductive Diseases, Hôpitaux Universitaires Paris-Sud. PC has served as investigator (principal or coordinator) for clinical trials funded by Novartis, Pfizer, Ipsen, Italpharmaco, Antisense, Prolor Biotech, and Chiasma. PC is a member of Advisory Boards from Ipsen, Novartis, and Viropharma. PC has been a member of the Advisory Board of HypoCCS sponsored by Eli Lilly. PC gave lectures for Ipsen, Novartis, and Pfizer. All the fees and honoraria are paid to his institution. The authors report no other conflicts of interest in this work.

\section{References}

1. Omnitrope ${ }^{\mathbb{B}}$ Summary of Product Characteristics. Available from: http://www.ema.europa.eu/docs/en_GB/document_library/ EPAR_-_Product_Information/human/000607/WC500043695.pdf. Accessed January 26, 2016.

2. Consensus guidelines for the diagnosis and treatment of adults with growth hormone deficiency: summary statement of the Growth Hormone Research Society Workshop on Adult Growth Hormone Deficiency. J Clin Endocrinol Metab. 1998;83(2):379-381. 
3. Pfäffle R. Hormone replacement therapy in children: the use of growth hormone and IGF-I. Best Pract Res Clin Endocrinol Metab. 2015;29(3):339-352.

4. Romer T, Peter F, Saenger, et al. Efficacy and safety of a new ready-touse recombinant human growth hormone solution. J Endocrinol Invest. 2007;30(7):578-589.

5. Romer T, Saenger P, Peter F, et al. Seven years of safety and efficacy of the recombinant human growth hormone Omnitrope in the treatment of growth hormone deficient children: results of a phase III study. Horm Res. 2009;72(6):359-369.

6. Peter F, Romer T, Koehler B, et al. 4 years of treatment with the rhGH Omnitrope $^{\circledR} 5 \mathrm{mg} / \mathrm{mL}$ lyophilized formulation in growth hormone deficient children: efficacy and safety results. Poster presented at: the LWPES/ESPE 8th Joint Meeting; September 9-12; 2009; New York, NY.

7. López-Siguero J, Borrás Pérez MV, Balser S, Khan-Boluki J. Longterm safety and efficacy of the recombinant human growth hormone Omnitrope ${ }^{\circledR}$ in the treatment of Spanish growth hormone deficient children: results of a phase III study. Adv Ther. 2011;28(10):879-893.

8. Borrás Pérez V, López-Siguero JP, Martínez G, et al. A follow-up study to monitor adult height among Spanish children with growth hormone deficiency who received biosimilar human recombinant growth hormone (Omnitrope $\left.{ }^{\circledR}\right)$ during a phase III clinical trial. Adv Ther. 2015;32(2):148-156.
9. Pfäffle R, Schwab KO, Marginean O, et al. Design of, and first data from, PATRO Children, a multicentre, noninterventional study of the longterm efficacy and safety of Omnitrope ${ }^{\circledR}$ in children requiring growth hormone treatment. Ther Adv Endocrinol Metab. 2013;4(1):3-11.

10. Pfäffle R, Kanumakala S, Höybye C, et al. Four-year results from PATRO Children, a multi-centre, non-interventional study of the longterm safety and efficacy of Omnitrope ${ }^{\circledR}$ in children requiring growth hormone treatment. Poster presented at: the 55th Annual Meeting of the European Society for Paediatric Endocrinology; September 10-12; 2016; Paris, France.

11. Schwarz HP, Birkholz-Walerzak D, Szalecki M, et al. One-year data from a long-term phase IV study of recombinant human growth hormone in short children born small for gestational age. Biol Ther. 2014; $4(1-2): 1-13$.

12. Schwarz HP, Walczak M, Birkholz-Walerzak D, et al. Two-year data from a long-term phase IV study of recombinant human growth hormone in short children born small for gestational age. Adv Ther. 2016; 33(3):423-434.

13. Romer T, Zabransky M, Walczak M, Szalecki M, Balser S. Effect of switching recombinant human growth hormone: comparative analysis of phase 3 clinical data. Biol Ther. 2011;1:5.

14. Rashid N, Saenger P, Wu YL, et al. Switching to Omnitrope ${ }^{\circledR}$ from other recombinant human growth hormone therapies: a retrospective study in an integrated healthcare system. Biol Ther. 2014;4(1-2):27-39.
Drug Design, Development and Therapy

\section{Publish your work in this journal}

Drug Design, Development and Therapy is an international, peerreviewed open-access journal that spans the spectrum of drug design and development through to clinical applications. Clinical outcomes, patient safety, and programs for the development and effective, safe, and sustained use of medicines are the features of the journal, which

\section{Dovepress}

has also been accepted for indexing on PubMed Central. The manuscript management system is completely online and includes a very quick and fair peer-review system, which is all easy to use. Visit http://www.dovepress.com/testimonials.php to read real quotes from published authors.

Submit your manuscript here: http://www.dovepress.com/drug-design-development-and-therapy-journal 